10 years ESJ

Special edition

\title{
Reformation of Criminal Justice System of Pakistan
}

\author{
Muhammad Arif Rajput, PhD \\ Visiting Faculty Member, Sindh Judicial Academy, Karachi, Pakistan \\ Farid Samir Benavides-Vanegas, PhD \\ Universidad Católica de Colombia, Colombia
}

Doi:10.19044/esj.2022.v18n5p87

Submitted: 12 November 2021

Copyright 2022 Author(s)

Accepted: 16 December 2021

Under Creative Commons BY-NC-ND

Published: 21 February 2022

4.0 OPEN ACCESS

Cite As:

Rajput M.A. \& Benavides-Vanegas F.S. (2022). Reformation of Criminal Justice System of Pakistan. European Scientific Journal, ESJ, 18 (5), 87.

https://doi.org/10.19044/esj.2022.v18n5p87

Abstract

This paper analyzes the loopholes and faults in the Criminal Justice System of Pakistan (CJSP), which is under rising criticism for its ineffectiveness and has been ranked at $108^{\text {th }}$ of the total 139 countries of the world in the Rule of Law Index, 2021. The poor and defective investigation by the police, without any effective prosecutorial or judicial supervision over the process of investigation, is mainly responsible for crippling the CJSP adversarial system, which needs to be reformed to make it effective. A comparative analysis will show that Latin American countries such as Chile, Argentina, México and Colombia have moved from an inquisitorial to an accusatorial system, claiming that this is the best way to protect fundamental rights and to reduce the ever-increasing impunity in these countries. By applying a comparative approach, it shows that both inquisitorial and adversarial system of justice have systematic weaknesses and strengths in their composition. This certainly has motivated the International Criminal Court (ICC), China, Spain, Italy and many other countries to develop an Adquisitorial System-mixed inquisitorial/adversarial system- to get the benefit of best practices of both the systems. The Pakistan case, in relation to the Latin American one, shows that what is important is not to analyze the system in the abstract, but to determine which one solves in a better way the problem a judicial system has: in Pakistan, law and order, given the limitations of police action; in Latin America, the protection of fundamental rights during the criminal process. The case in Pakistan shows that the problems the judicial 
system is facing can be solved by appealing to a combination of inquisitorial and accusatorial features. This paper concludes suggesting that the existing investigation phase of the CJSP should be transformed, by legal transplant, to an inquisitorial pre-trial investigation process, with necessary modifications, led by the investigative judge while the trial phase remains to be adversarial.

Keywords: Adquisitorial, criminal justice system of Pakistan, reformation, judicial reform, Latin America

\section{Introduction}

A criminal justice system is the main pillar of the rule of law in a country. The World Justice Project, in its report, has defined the criminal justice system as "the form of conventional mechanism to redress grievances and bring action against individuals responsible for offenses against society" (rule of law index, 2021). No country or society can survive long without an effective Criminal Justice System. The dominative components of the CJSP are investigation by the police, prosecution and trial by Courts (Lal Khan vs. $\mathrm{SHO}$ ). The law defines the function of each of these components. These components must be balanced within their respective domains and functions to get an effective Criminal justice system. However, the prevailing status of the CJSP is indicative of the fact that these components are not performing their functions coherently, which has made the CJSP crippling and ineffective. It is unfortunate that the CJSP has been ranked at the $108^{\text {th }}$ of the total 139 countries of the world in the Rule of Law Index 2021 (Rule of law index, $2021)^{1}$. Besides, Pakistan conviction rate ${ }^{2}$ is very low (low conviction rate; 2010). Although, courts are not meant just for recording convictions and a high conviction rate is not the primary objective of the criminal justice system (Rajput, 2020), but "it is a reasonably good indicator of the efficiency and efficacy of the criminal justice system prevailing in a country" (Ishikawa, 2019). In PILDAT research (2016), it emerges that the conviction rate in Pakistan is $8.66 \%$. Moreover, the International Crises Group, in its report (crisis group, 2010), has also commented that in Pakistan the conviction rate is $10 \%$, at best. People should be able to trust the justice system but, the evidence shows that this trust has been eroded. This has been translated into a situation of crisis of law and order in the country. People are now resorting to street justice and there are reports of incidents involving the killing in Courts

\footnotetext{
${ }^{1}$ The indicators used to measure a country's performance are: the criminal investigation system, the criminal adjudication system, the correctional system and the reduction of criminal behavior, impartiality, corruption, government influence, due process of law and rights of the accused.

${ }^{2}$ The conviction rate may be taken to mean the ratio of cases convicted out of the total number of cases decided in a given year.
} 
of people accused of committing crimes ("three under-trial", 2021). It may be due to a lack of understanding of the faults in the system that the public often demands the Courts to convict criminals with harsh punishment, including public hangings to deter the commission of serious crimes. However, merely harsh punishment will not yield the results until the justice system is made effective ${ }^{3}$.

It is not only the public who criticizes the effectiveness of the CJSP but the attorney general of Pakistan has also confessed the abysmal state of the CJSP. (Unfair Justice, 2020). The Islamabad High Court has also observed that the "current status of the criminal justice system does not appear to guarantee the fundamental right to a fair trial and justice to every citizen. The system has become a classic example of a grave violation of the constitutionally guaranteed rights of every citizen because it fails to achieve its fundamental objective to protect the victims, punish the guilty and thus make society safe for every person" (Aftab Hussain v. The State). On the decay of CJSP, the High Court has also observed that this poor status of the criminal justice system is the result of "the apathy, neglect and misgovernance of the past seven decades". The situation is going to be worst than ever. The courts are facing the backlog of 2.18 million cases (Consolidated Statement, 2021). This burden outweighs the capacity of police to investigate and prosecute (Imtiaz, 2014). This is mainly because of the continuous inflow of weak and false cases in the system, without any gate keeping role of the prosecutor or judges, resulting in the judicial paralysis of the entire CJSP. Cognizant of the fact, the then Chief Justice of Pakistan has also observed that even if the entire judiciary of Pakistan, consisting of 4000 judges, works round the clock, it cannot clear the backlog. ("4000 Judges", 2018). As per report of the Prime Minister's Prisoner Reform Committee (PPRC), $65 \%$ of the inmates of jails are under-trial prisoners (UTP's), which is indicator of the "sluggishness of the judicial system ("under-trial prisoners", 2020). This prolonged pre-trial detention has become a human rights problem and is evident of the fact that the legal apparatus is inept to effectively impart justice. In short, the current state of the criminal justice system is not serving its purpose and seems to be on the verge of collapse.

${ }^{3}$ In Latin America there is also a pressure to apply harsh punishment to people convicted of committing grave crimes. Whenever crimes such as rape or attacks against children occurred, public opinion is created to call for the use of the criminal justice system to solve these social problems. In the analysis reformers make, they do not pay attention to the flaws in the investigation process or the limitations of the police. Given the lack of structural reforms, reformers usually ask for changes in the penalties, because this is the best way to show that a problem has been solved, without actually doing it. On punitive populism in Latin America see (Basombrio \& Dammert, 2013 and Dammert, 2019). 
The High Court, while emphasizing the needs of urgent reformation, has observed that if urgent steps are not taken then posterity will never forgive those who are today in a position to remedy the wrongs that perpetuate miscarriages of justice (Aftab Hussain $v s$. The State). The voices on the broken state of the CJSP are also coming from the international community. In a report of the International Crises group (2010), it has been noted that "Pakistan's dysfunctional criminal justice system poses serious risks for domestic, regional and international security" and has stressed upon the reformation of CJSP on top priority basis.

In the past, many efforts had been made to bring amendments in the legal framework to enhance the effectiveness of the system but those efforts were revolving around the same old outdated laws, procedures and practices, and they had not brought any positive results (Jamshed et al., 2013). Unless the root cause of the problem is addressed, no reform in the system would give any result. This research focuses on the problems and weaknesses of the system and to find out most suitable remedial measures to reform it so as to make it effective and speedy. It takes a comparative approach to show how similar problems were addressed in other regions and judicial systems.

The study aims to diagnose the problems in CJSP and after having the insight of the problems, suggests reforms through a comparative approach.

\section{The Latin American Path for Structural Reforms in the System}

Pakistan is not the only country in the world that has faced the need for structural reform of its judicial system. In Colombia, the 1980s were characterized as a time when the criminal justice system did not work and increasingly became the weakest branch of government (Bickel, 1962). During a long time, Colombia had an inquisitorial system of justice, given its history as a Spanish colony. This system gave all the powers to judges, to investigate and try. All the stages of the criminal process took place before the same person, which led to critics to hold that once a person had been accused of a crime, it was very likely to be convicted. The role of the police was minimal, because they were in charge of bringing suspects before the judges, but the whole investigation was done by the judges with the help of the police (Urbano, 2008).

The judicial system of justice had few resources, corruption was generalized and it was very common for judges to work without pay for months. Of course, this led to a big backlog of cases and to an almost complete failure of the system. At the same time, the country faced several threats from organized crime and guerrilla's attacks. Many judges were killed during these years. In response to these attacks, a special system of justice was created. One in charge of investigating and trying members of these organizations. In order to protect judges, the system reserved the identities of judges, witnesses 
and representatives of the ombudsperson office. Because of that it was called "faceless justice" (Benavides, 2015).

Because of this crisis, in 1987 a new system was introduced. In this one, there was a separation between the judge in charge of investigating and the one in charge of trying cases. This gave some legitimacy to the process, given that convictions were not predetermined in the indictment. However, in general, it was a judicial process, with a judiciary without the necessary resources to face the criminality of the country and with the police under the guidance of judges, but without actual control of the investigation.

In 1991, as a result of the need of a new constitutional pact, a new political constitution was passed. In this Constitution, the Attorney General's Office was created and it had the power to investigate all crimes and it had control over the investigatory powers of the police. This office was part of the judicial branch, which gave it some judicial powers, such as ordering the detention of a person without judicial control. Due to what was considered as an excess in the powers of the Prosecutor, a new reform was made. In 2000, the new reform came into force. It created the Judge of Guarantees, in charge of checking that a detention ordered by the prosecutor was legal. For some people, this reform was not enough, because they considered that for a system of law that protects the defendant rights there needs to be a separation between the prosecution and the judges. For that reason, in 2004 an accusatorial system was established. The main arguments given to support the transformation of the criminal justice system was the need to protect people's rights and, surprisingly, to have stable rights to protect foreign investment (Benavides, 2008).

As a result of these reforms, Colombia now has an accusatorial system. In the region, due to the pressures of the IMF and the World Bank, the judicial system of Mexico, Chile, Perú and Argentina have changed to an accusatorial system, because, according to reformers, this is the best way to have an efficient system of justice and to protect human rights. The Latin American case shows that the path in the transformation of the judicial system goes from an inquisitorial to an accusatorial system. However, the Pakistan case shows us a different story.

\section{Method}

In this research, "doctrinal legal research" methodology is employed. A descriptive diagnostic approach has been adopted to identify the main problems in the CJSP. The comparative approach is adopted to find out the solution of the research problem by analyzing the Adversarial and Inquisitorial system of justice. To achieve result-oriented reform, the technique of legal transplant- moving a rule from one jurisdiction to another- is used in a comparative approach. For this article, both primary (statute) and secondary 
data including books, articles, case-laws, reports and reputed journals have been analyzed.

\section{Analysis of the CJSP in Search of a Diagnosis}

In order to diagnose the problems of the CJSP, a cursory visit to the functioning and limitations of the dominant components of the CJSP needs to be made. It would also help to look for the best way to improve its performance.

\section{1) Investigation by Police}

Like other countries, the Police is the point of entrance to the CJSP. Reporting of the crime by the individual by registration of a F.I.R (first information report) at a police station sets the system into motion. After the F.I.R, it is the responsibility of the investigating officer (I.O) to investigate as to who has committed the offence; collect the evidence, ascertain factual circumstances; arrest the accused; and bring all these before the Court to determine the guilt or otherwise of the accused, to secure the ends of justice (Lal Khan vs. SHO). On concluding the investigation, if the I.O makes her/his view that the case is made out, s/he submits a positive report/charge sheet, through the public prosecutor, in the Court of the Judicial Magistrate for trial by the said Court or the Court of Sessions, depending on the case. The second Schedule of the Criminal Procedure Code, 1898 (Cr.P.C) prescribes the trial Court for the particular offence. However, in case the I.O concludes that the case has no grounds, s/he submits a Negative Report/Final Report to the Judicial Magistrate for its approval. During the investigation, the I.O has also the power to release the accused against whom no evidence of involvement is found (Criminal Procedure Code, 1898).

\section{Role of the Judiciary in Investigations}

In the CJSP, the investigation process remains out of the court, and judges have only limited say in it. Ordinarily, the Courts do not interfere in the investigation of a criminal case (Muhammad Farooq vs. Judicial Magistrate). The Supreme Court of Pakistan, in the case of Muhammad Ali (2014), has held that the High Court has no jurisdiction to interfere in the investigation of a criminal case. The concept behind it is that the accused would be at liberty to put forward her/his defense before the Trial Court (Abdul Ghaffar vs. The State).

\section{2) Prosecution}

After submission of a charge sheet by the police in Court, the public prosecutors represent the State before the Courts. Under the law, the prosecutor has also the duty to scrutinize the positive/negative report of police 
to ascertain if the case has merits to go to trial or not (Punjab Criminal Prosecution Service, 2006).

\section{3) Courts}

The trial of the cases is being carried out at the district judiciary comprised of Magistrate Courts and Sessions Courts, and in some cases, under special laws, trials are being held by the Special Courts/Tribunals. Prior to the formal trial, copies of the proceedings are supplied to the accused. The trial of the case starts with the indictment informing the accused about the nature of the case against him. In case the accused pleads guilty, s/he may be convicted by the Court. In case, s/he does not plead guilty, the prosecution's evidence is recorded with opportunity of cross examination to the defense counsel. Normally, after the prosecution provides all the evidence, the indictment is recorded and the accused is given the option to produce evidence in her/his defense. In the end, after hearing the arguments from the public prosecutor and the defense counsel, the judgment is pronounced by the Court convicting or acquitting the accused, as the case may be, on the basis of material evidence produced on record by the prosecution (Criminal Procedure Code, 1898).

\section{Diagnosis of the Problem}

The above analysis of the roles and limitations of each of the components of the existing CJSP would show that the investigation conducted by the police is the foundation of the system. It is said that "a case is as strong as its evidence" and, in the CJSP, the police are entrusted with this duty of collection of evidence in the investigation. In the Court, the prosecutors have to rely on the evidence collected in the investigation, which ultimately determines the fate of a case. Under the law, a positive or negative report of the result of investigation is subject to scrutiny by the public prosecutor prior to its submission before the Judicial Magistrate. The purpose and importance of such scrutiny has been highlighted in the report of the Prime Minister's Prisoners Reforms Committee (PPAC), in a way that "to ensure the drop of proceedings at an early stage in case of lack of evidence, early consultation of police with prosecutors needs to be enhanced ("under-trial prisoners", 2020)." However, in practice, prosecutors do not have an effective input in analyzing, examining and evaluating the evidence collected by the police (Crisis Group, 2010). Peter (2014) has noted that in practice, the opinion or advice of the public prosecutor is not binding for the investigating officer, leaving the prosecutor toothless. Her/his role has been limited to that of a postperson between Police and Judiciary (Jamshed, 2018). Likewise, normally, the courts do not interfere in the process of investigation (Muhammad Ali vs. Additional I.G). The fact remains that an effective investigation is a condition precedent for ensuring that actual perpetrators of a crime are prosecuted and 
sentenced after proving them guilty in Court (Noor Hassan vs. State). In such a way, the structure of entire CJSP rests upon the investigation conducted by the Police. However, the analysis reveals that in the CJSP there is no effective supervision over the process of investigation either by the public prosecutor or the judges/courts.

\section{The Chronic Problems in the CJSP}

The Supreme Court, in the case of Watan Party (2011) has shown its resentment against the representative of the government, who criticize the courts for the release of alleged terrorists and criminals. It was observed that "Courts can only act upon evidence and material presented before them, which is collected by the police, therefore the Courts cannot be blamed if the police fail in their duty" (Watan Party v. Federation of Pakistan). The then Chief Justice of Pakistan, Iftikhar Muhammad Chaudhry, in his speech has identified the root cause of the ailment of the CJSP by asserting that "due to defective and careless investigation and weak prosecution, a large number of terrorists and criminals get released by courts, which is not only lowering the image of judiciary but also encouraging the criminals (Peter, 2014)." In a similar way, the attorney general of Pakistan has confessed that "the deep flaws in the investigation and prosecution processes allow criminals to get away with their crimes" (Unfair Justice, 2020). In a survey, on the rule of law in Pakistan, the World justice project showed that the investigation phase is the most serious problem that the CJSP has (the rule of law in Pakistan, 2017). The statistics also affirms their diagnosis. The conviction rate in Pakistan is $8.66 \%$, which is very low as compared to the other technologically developed countries like Australia, U.S.A and England (PILDAT, 2016). This unreasonably low conviction rate is indicative of poor and defective investigation. The Supreme Court of Pakistan, in the case of Haider Ali, while emphasizing the need of reform of the criminal justice system, has observed that low conviction rates are mainly indicative of weak investigation and gathering of evidence (Haider Ali v. DPO Chakwal). There is another dimension of the effect of poor investigation on the fate of a criminal case. A report, published in 2018 by Justice Project Pakistan, has unveiled that since the year 2014 till the year 2017 the Supreme Court of Pakistan has commuted the death sentences or acquitted $85 \%$ of the accused during appeals, mainly on the basis of defective investigations and evidence (Justice Project Pakistan, 2018). No doubt, the judgments are handed down by the Courts, but these judgments are given on the basis of the evidence that has been produced during the trial of the case by the Police. Thus, if the investigation is not properly conducted and the reliable evidence has not been produced in the court, then what can a trial judge do? In the adversarial system of justice, where law requires "proof beyond any reasonable doubt", the trial judge is left with no choice except to acquit the 
accused by giving her/him the benefit of the doubt (Watan Party $v s$. Federation of Pakistan). One of the classic examples of such cases is Mukhtaran Mai gang rape case (State $v s$. Abdul Khaliq), wherein due to failure to conduct the semen matching test and DNA, the accused were acquitted. In Pakistan, even the cases of homicide are being investigated by the low ranked, nonprofessional and untrained police officers, who have unfettered powers in the investigation. The Islamabad High Court in the case of Aftab Hussain (2021) has observed that the "incompetence, outdated and obsolete techniques used for investigating the case and lack of probity and professionalism of the investigating officers, are the root causes of the broken justice system". Further, it is observed that "there is no independent, separate investigation branch and it appears that this is not a priority and the procedures and laws have become outdated and a cause for delays" (Aftab Hussain vs. The State). The above review clearly demonstrates that the basic root cause of failure of CJSP lies with the investigation of the case by the police. Expecting good results in such state of affairs would not be more than a night dream. This has not only eroded public confidence in the judicial system but it also creates a sense of helplessness, frustration and anguish amongst them. The prevailing situation demands radical reforms in the process of investigation by the Police (Azeem, 2019).

\section{Pathways to Reform the CJSP}

To address the flaws in investigation and ineffective police supervision, the Police Reforms Committee formed by the Chief Justice of Pakistan, in the year, 2010, made some recommendations. However, it is not a secret that except the mere recommendations about reforms in the investigation system, nothing appears to have been done. Likewise, various Law Reform Commissions and Committees were formed for judicial reforms. They carried out a comprehensive analysis of the procedural laws and rules and recommended various measures for reformation. Those measures were centered to existing laws and procedures but they could not improve the situation (criminal justice system, PKLJC 22). Hence, the solution should be searched beyond the sphere and boundaries of the existing justice system; otherwise nothing could be achieved except superficial measures that attract more to optics than substance. To find out the way out, the prevailing systems of justice in the world have to be explored.

\section{Types of Criminal Justice Systems}

The Criminal Justice Systems vary from country to country. However, they may be mainly categorized in five groups or patterns i.e. adversarial systems or accusatorial (common law), inquisitorial systems (civil law), customary law, religious (usually Islamic) law, and mixed or hybrid legal 
systems (international legal systems). However, most of the countries of the world are following Adversarial Systems or Inquisitorial Systems, therefore these two would be in focus to dig out the answer to this paper research problem (Ainsworth, 2015).

\section{Adversarial System of Justice}

The CJSP is still using British laws, and it follows the Adversarial System of Justice (Mehmood Ali vs. The State). The Adversarial System is also being followed in many countries of the world including Australia, Bangladesh, Canada, Hong Kong, India, Kenya, Malaysia, New Zealand, Nigeria, Singapore, Tanzania, Uganda, United Kingdom and the United States (Ainsworth, 2015). In adversarial proceedings, the parties and their advocates prepare and present their cases in the Courts and the judge plays a passive role and has to act as a neutral person or an umpire (Ali, 2015). The earlier decisions of the higher Courts are binding precedent upon the sub-ordinate Courts of the Country ("Constitution", 1973). In the CJSP, like other adversarial systems, the accused is treated as innocent unless proven guilty and the prosecution is under the obligation to prove its case against the accused at the standard of proof required in criminal cases, namely, beyond reasonable doubt (Naveed Asghar vs. State).

\section{Inquisitorial System of Justice}

The inquisitorial system is based on the principle of the official investigation led by judges, which gives a much wider power to judges to supervise the process than they have during the adversarial proceedings (Nachkebia, 2016). In this system, a comprehensive pre-trial investigation and interrogations are carried out aimed to evade bringing an innocent person to trial. In other words, it can be defined as an official inquiry to ascertain the truth, whereas in the adversarial system, a competitive process is used between the prosecution and the defense for the determination of the facts (Dammer \& Albanese, 2014; Reichel, 2017). Unlike the Adversarial system, in this system, the police submit a dossier (case file of evidence) to the investigating judge/magistrate, who then examine the dossier and make queries to the witnesses in preliminary court hearings. This judge/magistrate is entrusted with the responsibility to lead criminal investigations, which includes, but it is not limited to, questioning the accused, victims and witnesses; ascertain the proper kind of evidence to be heard. Her/his duties also include the preparation of the case file to be forwarded to the trial/sitting judge for their decision. In this system, the investigating judge has been bestowed with vast powers, including issuing warrants of arrest and visiting the scene of the crime. Soon after completion of investigation, the investigating judge can refer the case to a sitting/trial judge for the formal trial of the case. The trial judge conducts the 
trial in Court and decide the guilt or otherwise of the accused. (U.S Department of Justice).

\section{Adversarial Systems Versus Inquisitorial Systems}

In comparing the two systems, the authors are not advocating as to which system of justice is better as both systems have some advantages and disadvantages (Sayed et al., 2019). However, the purpose of this comparison is to clarify their basic features, as well as, their strengths and weaknesses.

Both systems have supporters and opponents. The supporters of an inquisitorial system argue that in the investigating phase, the investigative role of a judge to unearth the truth helps the trial court in determining the prima facie case of the prosecution. It is also advocated that this investigative role of a judge also provides affordable justice to parties, who are unable to hire high profile lawyers (Rani, 2006). The supporters of the Adversarial system, on the other hand, argue that providing the opportunity to litigants to present their case before the Court is the only way to achieve justice. The critics of the adversarial system dismiss this argument by questioning the facts presented by the adversaries before the Court because lawyers are masters of a game of twisting the facts (Rani, 2006). This debate of dominance of one system over the other is termed as "unfettered discourse" among the scholars of procedural law (Pakes, 2007). We probably cannot know as to which justice system is accurate in fact-finding, and efficient in its delivery as there is no verifiable way of gauging it (Ainsworth, 2015).

As the Latin American case shows, the option for one system or another is not related to the merit of the system in itself, but to the needs that the particular criminal justice system has. From a strict human rights point of view, the Latin American reform appeals to the idea that the best way to solve the problems of the system is by implementing an accusatorial system. Some commentators characterized the accusatorial system as an imperative of humanity and as a mandate of the international community. One of the main elements deals with the need to bring all the evidence during the trial, so the judge can be present in their practice (Urbano, 2008). Perhaps, this is the main limitation of the Spanish inquisitorial system, given that it is important for the trial judge to be present at the moment where the evidence is collected and to hear directly the testimony of witnesses. This is one of the reasons why Latin American countries moved to an accusatorial system, to guarantee the right of the defendant to have all the evidence presented in trial and not before it. But this is a problem that can be solved by guaranteeing that the trial judge listens to the evidence in trial, but, in any case, keeping judicial control of all the investigation process. 


\section{Remedial Measures}

The study and analysis have established that the root cause of the ineffectiveness of the CJSP is the poor investigation led by the police officer without any active prosecutorial or judicial supervision over such crucial process. In different jurisdictions, the structure and dynamics of pre-trial investigation is diverse. However, they may conveniently be grouped in three categories. Firstly, supervising or directing investigation is entrusted to the prosecutor. Secondly, an investigative judge or magistrate is assigned the dominant supervisory role in the pre-trial investigation. Thirdly, in some jurisdictions, this supervisory/directory role is shared by the prosecutor and the judges as per the nature of the offence. However, choosing one of them to fit in the CJSP cannot be done in isolation. As King et al., (2009) argued, "the justice system does not exist in isolation". To a significant degree, it reflects beliefs and norms that exist in the country. Scrutinizing the role of the prosecutor in CJSP would show that had the prosecutors applied a legal version of triage whereby they dropped the weak cases at the initial stage before the trial, the situation of the CJSP would not be so bad. This excludes assigning a supervisory role to the prosecutor. One of the guiding factors in this exploration is to find out the level of trust of Pakistan people on the institutions. In a survey, on the rule of law in Pakistan, by the world justice project, across institutions, the public in Pakistan have shown their most trust in the courts $(61 \%)$ and the least trust in the police (23\%) (the rule of law in Pakistan, 2017). This leads to the option that the pre-trial investigation be placed under direct effective and authoritative supervision of Judge/Magistrate. As to the modus operandi, theoretically, there are two options to be considered: first, the framework of the Adversarial system, second, to seek refuge from the inquisitorial. This is because, in these two systems, judges have different roles. In adversarial systems, the role of the judge or the magistrate at the stage of investigation is passive, leaving the facts to be determined at the trial. However, in Inquisitorial systems, the investigating judge/Magistrate has an active role in investigating the facts of the case.

The justice system of the United States has been considered as a typical adversarial one. Inspiring from it, many Latin American countries including Argentina, Bolivia, Colombia, Costa Rica, Chile, the Dominican Republic, Ecuador, El Salvador, Guatemala, Mexico, Nicaragua, Paraguay, Peru, and Venezuela, have transformed from their historically traditional inquisitorial criminal justice systems to an American adversarial justice system (PulecioBoek, 2014).

However, it is interesting and point to ponder that many scholars, including Michael Risinger and Lesley Risinger (Risinger, 2012), insist for radical reformation in the American justice system. They suggest that the 
responsibility to unveil the truth should be given to an investigative judge. They propose that the judge should supervise investigations by the Police and make all information equally available to the prosecution and defense, which was collected by the police in a pre-trial investigation. Another scholar, Christopher Slobogin (2014), advocates for a more active role of judges and proposes that instead of the parties, the trial judge should be entrusted to regulate as to which evidence is required; to interrogate the witnesses and also liberally appoint expert witnesses to assist her/him in fact-finding. Slobogin has also argued that the accused who claims innocence shall give his statement at pre-trial stage. In similar fashion, Samuel Gross (Gross, 2011/2012) has argued that the accused, who maintains innocence, should waive her/his right of silence and answer the questions by the investigating official, during investigation, and her/his testimony should be recorded at the trial. However, mandatory statement of accused at a pre-trial stage would violate her/his guaranteed constitutional right that "no person shall be compelled to be a witness against himself" (“Constitution", 1973).

Risinger's idea is that the pre-trial investigation process should be supervised by a judge/Magistrate while Gross and Slobogin suggested the role of trial judge to be of more active investigator rather than a silent spectator between two players. This appears to be very similar to the role played by an investigating judge in France. Slobogin proposes a system that is 'a hybrid between pure adversarial and pure inquisitorial system of justice." It is very close to the procedural law that is already in existence in a number of civil law countries (Slobogin, 2014). In the context of the CJSP, Slobogin's suggestion that the statement of accused, without oath, is to be taken at trial appears to be alike to the position in Pakistan. In this scheme, even if the accused tells a lie in her/his statement in Court, s/he is not liable to any adverse consequences. Raneta Lawson Mack (2006) noted that the American adversarial system is broken and it is in desperate need of reform. She suggests that the incorporation of an inquisitorial soul into the adversarial body of the American system would provide a safeguard against the wide discretion of the police and prosecutor while protecting the due process and protection of individual rights. She argues that this would "promote a truth-seeking objective that would likely produce fair, uniform results and contribute to enhanced overall confidence in the American criminal justice system" (Mack, 2006).

US scholars are not alone in proposing that the adversarial system can acquire best practices from the inquisitorial system. In adopting the inquisitorial approach, Scotland has made the pre-trial disclosure from prosecution and defense mandatory in serious offences (Duff, 2007). In Scottish law, the accused has to file a 'defense statement' in Court, setting forth the nature of any defense, any matter of fact like a plea of alibi, self defence etc. and any legal point the accused want to make (Criminal Procedure 
(Scotland) Act, 1995). Interestingly, the British have also reformed their law, but Pakistan still continues using the legacy of laws left by them. Their approach is also moving towards an inquisitorial system (Johnston, 2016). Similar to the Scottish scheme, England and Wales, from whom Pakistan had inherited its system of justice, in 1996 reformed their procedural law to have a system with disclosure on the pre-trial stage, instead on the trial itself. This has modified the role of a passive trial judge to an active role as s/he is equipped to call up pre-trial hearings in order to narrow down the disputed issue.

Commenting on the Pre-trial defense disclosure in South Australian criminal proceeding, Line et al. (2016) observed that in a pre-trial reformation, criminal procedure appears to be shifting from pure adversarial to inquisitorial. Lord Justice Auld (English criminal procedure, 2010) has commented that "A criminal trial is not a game under which a guilty defendant should be provided with a sporting chance. It is a search for truth..." (Auld, 2001). No doubt, no sweeping statement can be given that an inquisitorial system is better at truth-finding than an adversarial system, or vice versa as we do not know the statistics of the innocent convicted and guilty acquitted. However, the above developments in the various jurisdiction and the trend of Latin American countries leads to deduce that the fact-finding of the adversarial system would be improved if some of the rules of inquisitorial are grafted in it.

The fusion of the two systems of justice is neither a hypothetical nor a new thing. It is a concept to attain sustainable justice by merging the best practices from the adversarial and inquisitorial. The International Criminal Tribunal for the former Yugoslavia and the International Criminal Court (ICC) have developed a procedure of proceedings containing the characteristics of a mixed inquisitorial/ Adversarial System (Peake, 2014). This development is not limited to the international bodies but many countries, as a result of historical evolution, have been shifted to hybrid systems of justice combining some features from one into another. (Rani, 2006) The other examples could be found in the South African Laws (Quadri et al., 2019). The Republic of Ireland, Spain, and Italy have adopted a mixed inquisitorial/adversarial system in 1988 (Michael, 1992). Quadri et al. (2019) stressed that to achieve sustainable justice, blending of the best practices of both systems will form an effective system. They have named the fusion of two systems as "adquisitorial".

Specific to the supervision of investigation being discussed here, in Spain, Italy, The Netherlands, Denmark, Portugal, Sweden and Russia, the pre-trial investigations are inquisitorial, with some differences, and the hearing is proceeded according to the adversarial principle. Likewise, China has transformed its justice system from inquisitorial to a mix of the adversarial 
and the inquisitorial (Liu \& Situ, 1999). While assessing as to which justice system is better suited than the other to be applied in investigation phase, Kai Ambos (2003) has suggested that "the civil law approach seems to be advantageous with regard to the equality of arms between Prosecution and Defense".

Keeping in view the research problem, the comparative study of both systems would show that in inquisitorial systems, there is effective supervision of the investigating judge over the pre-trial investigation phase. In the given scenario, adopting the inquisitorial system of justice at the stage of investigation, with certain modifications to ensure the rights of victim and accused are protected, can bring the benefits of both systems. However, it is suggested that the trial remains to be conducted in adversarial system, as it is. Alan Watson claims that "legal transplantation is an important source of legal development because the country that is borrowing the rule takes advantage of the experience of the application of the rule" (Spamann, 2009). Therefore, in order to import the best practices of the inquisitorial system of justice for the investigation phase of Adversarial CJSP, the technique of legal transplant is suggested to be employed.

In the study of the Criminal justice system of the world, it emerges out that there is a global tendency of increase in the use of plea bargaining in criminal cases. Although, this is not without criticism but it is considered to be one of the best tools to substantially reduce the burden placed on courts and prisons (Thaman \& Stephen, 2010). For instance, in Italy, under the Cr.P.C, 1989 there is a provision of avoiding full trial by a process of "agreed sentence ${ }^{e e}$. This allows the prosecution and defense to agree on the appropriate sentence, without going through a full-fledged trial, however, subject to judicial review (Ma, 2002). However, in the CJSP, there is no provision allowing the plea bargaining except in the cases of National Accountability Bureau (NAB). The introduction of the provision of plea bargaining in the CJSP is the need of the hour. ${ }^{4}$

\section{Conclusion and Recommendation}

Currently, in Pakistan, there is a huge interest for research in judicial reforms. However, the available research revolves around the same procedures, laws and practices, which remained unsuccessful in the past. In this paper, the authors tried to comprehend the loopholes and weaknesses in the CJSP and tried to briefly review those problems grounded on the adversarial justice system. The study of literature shows that that amongst the three dominant pillars of the CJSP, the investigation by police is mainly

${ }^{4}$ On the use of plea bargain as a way to solve the backlog of cases see (Hakim \& Zulhuda, 2020; Velásquez, 2019; Gupta \& Agrawal, 2018;). 
responsible for the crippling and broken justice system of Pakistan, which urgently needs reformation. Distinct from the previous literature and to move a step forward, from the earlier research, the comparative qualitative study of the inquisitorial and adversarial system of justice, as well as, the fusion of both has been done. This unveiled that the trend of sticking to only one system of justice is transforming to have a mixed of both inquisitorial and adversarial to get benefits from the best practices of both. This is being followed in many countries including China, Spain, Italy, The Netherlands, Denmark, Portugal, Sweden, Russia and international tribunals including the International Criminal Court (ICC). This study leads to conclude that the investigation phase of CJSP may be replaced, by legal transplant, mutatis mutandis, with the Investigation phase of inquisitorial system and rest of the procedure of CJSP, which is adversarial, may be retained as it is. It is recommended that the plea bargaining for minor offences may be introduced in the CJSP, which would substantially reduce the burden placed on courts and prisons. This agreed sentence, as in Italy, may include the rehabilitation, probation and fines.

This paper shows that legal reform needs to pay attention to the problems it needs to solve. There is no best criminal justice system in the abstract. To choose one or another system we need to consider the problems we need to solve and the legal culture of the country. In Latin America, for instance, the main problems were the efficiency of the system, as well as, the protection of human rights. The transparency that was found in the adversarial system was considered the best way for the protection of defendant's rights. The case in Pakistan shows that the problems the judicial system is facing can be solved by appealing to a combination of inquisitorial and accusatorial features.

One research paper is not sufficient to cover all the components of CJSP for reformation. It has only suggested the pathway to move forward in a certain direction to achieve the desired results to make the CJSP effective. To make the system viable with the borrowed rules, there is much needed reformation for the other components of this system too. However, such reforms must be backed with meaningful research, which keeps in view social challenges, norms of society and the constraints of CJSP. It is suggested that judges from district judiciary to Supreme Court, Prosecutors, advocates, criminologists, law enforcement agencies, academia specially from the judicial academies, researchers and public policy makers should come together to successfully bring reformation in the CJSP. Based on their findings, recommendations should be sent to the Ministry of Law and Justice for the introduction of new laws, as well as, for refinement of existing ones. However, till the complete reformation is researched, recommended and articulated, the following steps may be taken: 
- In the initial phase, the reformation may be implemented as a pilot project in one district for the heinous crimes only such as, rape, murder, molestation of child, injury cases etc., wherein the investigation is to be led by the instruction/investigative judges/Magistrates. In the case of Colombia, the implementation of the system was done in different stages, so the problems that were arising could be solved before the system came fully into force in all the country.

- Police, other law enforcing agencies and prosecutors should be legally bound to assist the Magistrates in this task.

- The Magistrates performing duties as instruction judges/Magistrates must be provided adequate training to effectively deal with the task.

- The judicial police department may be created.

\section{References:}

1. Ainsworth, J. (2015). Legal Discourse and Legal Narratives: Adversarial versus Inquisitorial Models; Language and Law/ Linguagem e Direito, Vol. 2(1), p. 1-11

2. Abdul Ghaffar v. The State through DG FIA, H.Q Islamabad (2021 P Cr. L J Note 14 -G.B)

3. Aftab Hussain v. State (2021 P Cr. L J 761 [Islamabad))

4. Ali, S. H. (2015). An Analytical Study of Criminal Justice System of Pakistan (with special reference to the Province of Punjab). Journal of Political Studies, Vol. 22 (1), 17:42

5. Ambos, K. (2011). International Criminal Procedure: 'Adversarial', 'Inquisitorial' or Mixed? Third International Criminal Law Review, Vol. 3, pp. 1-37.

6. Auld, LJ., (2001). A Review of the Criminal Courts of England and Wales, Chapter 10, at [154].

7. Azeem, M.H., (2019, Sep. 14). Police reforms: Causes, outcomes and a way forward. Daily Times.

8. Benavides-Vanegas. F.S. Control penal del crimen organizado en Colombia 1980 - 2014. Bogotá: FES Seguridad, 2015.

9. Benavides-Vanegas, F.S. 'A global Zero tolerance? Colombian prisons from a world historical perspective. Revista Pensamiento Jurídico No. 23. (2008). Pp. 173-202.

10. Consolidated Statement (31 ${ }^{\text {st }}$ August, 2021). Law and Justice Commission of Pakistan. https://ljcp.gov.pk/nljcp/assets/dist/news_pdf/courts.pdf

11. Constitution of Islamic Republic of Pakistan, 1973 Articles, 13, 189, 201 and 203 GG

12. Criminal justice system - PKLJC 22. (n.d.). and Expediting trial proceedings-PKLJC 60. Asian LII-Asian Legal Information Institute. 
http://www.commonlii.org/pk/other/PKLJC/reports.html. See also Police Reforms Committee Report. (2018). Police Reforms: Way Forward. Law and Justice Commission of Pakistan. Retrieved from http://ljcp.gov.pk/nljcp/\#1

13. Criminal Procedure Code, 1898, Pakistan (Cr.P.C). Sections 173, 169, 265-C, 265-D, 265-E, 265-F, 265-G, 265-H, 342 and 340 (2)

14. Crisis Group, Asia Report $\mathrm{N}^{\circ} 196$. (Dec. 6, 2010). Reforming Pakistan's Criminal Justice System, International Crisis Group., retrieved from http://www.crisisgroup.org/en/regions/asia/southasia/pakistan/196-reforming-pakistans-criminal-justice- system.aspx

15. Dammer, Harry R. and Jay S. Albanese (2014). Comparative Criminal Justice Systems, 5th ed. And Wadsworth. Reichel, Philip. (2017). Comparative Criminal Justice Systems: A Topical Approach, 7th ed. Pearson.

16. Dammert, Lucía. ‘¿Reformar sin gobernar? Desafíos institucionales de las policías en América Latina'. Revista de Instituto de Ciencias Jurídicas de Puebla vol. 13 No. 44. Julio - Diciembre 2019. Pp. 89 120.

17. Dammert, Lucía \& Basombrío, Carlos. Seguridad y populismo punitivo en América Latina. Lecciones corroboradas, constataciones y temas emergentes. Washington: Woodrow Wilson Center, 2013.

18. Duff, P. (2007). 'Disclosure in Scottish criminal procedure: another step in an inquisitorial direction'. International Journal of Evidence \& Proof, Vol.(11)- 153.

19. Gross, S.R. (2011/12). Pretrial incentives, post-conviction review, and sorting criminal prosecutions by guilt or innocence. New York Law School Law Review. Vol.56. (56 NYL Sch L Rev 1009-1030).

20. Gupta, L. \& Agrawal, P. (2018). Judicial backlog: how India can end the long wait for justice. Daily $O$.

21. Haider Ali and another v. DPO Chakwal and others (2015 S C M R 1724).

22. Hakim, L. \& Zulhuda, S. (2020). Plea Bargaining as a solution for criminal case backlog in Indonesia. International Journal of Psychosocial Rehabilitation vol. 24 Issue 05. Pp. $281-291$.

23. Imtiaz, G. (2014, July 1). Terror, Crime and the Tardy Justice System. Express Tribune.

24. International Legal Systems. An Introduction, U.S Department of Justice, National Security Division Washington, DC: https://www.justice.gov/archives/nsd-ovt/page/file/934636/download

25. Ishikawa, K., Ngo Mandeng, P., Sharma, M., \& Mwalili, J. (2019). Issues Concerning Prosecution In Relation To Conviction, Speedy Trial and Sentencing (Rep.). Int. Trg. Course. P.348-367. Retrieved 
from

https://www.unafei.or.jp/publications/pdf/RS_No53/No53_31RC_Gr oup3.pdf107th

26. Jamshed, Hamza. H, Kamil. (2013). A study of Criminal Law \& Prosecution System in Pakistan. Manzil Pakistan.

27. Jamshed, J. (2018). Criminal Justice System in Pakistan: An Overview. Available at SSRN: https://ssrn.com/abstract=3152735

28. Johnston, E. (2016). All rise for the interventionist: The judiciary in the 21st century. Journal of Criminal Law, 80(3), 201-213. https://doi.org/10.1177/0022018316647870

29. Justice Project Pakistan. (2018). Counting the Condemned. Retrieved from https://jpp.org.pk/report/counting-the-condemned/

30. K., \& T. (2016). Victims and the Criminal Trial (978th-1st-137th51000th-6 ed. ed., Vol. 1). Palgrave Macmillan UK. https://doi.org/10.1057/978-1-137-51000-6

31. King, M.S. (2009). Solution-Focused Judging Bench Book, Melbourne, Australasian Institute of Judicial Administration, www.aija.org.au/Solution\%20Focused\%20BB/SFJ\%20BB.pdf

32. Lal Khan and another v. SHO, P.S Kotwali, Jhang and 6 others (2010 P Cr. L J 182 [Lahore])

33. Line. L, Wyld. C, Plater.D, ((2016).Pre-trial defence disclosure in South Australian criminal proceeding: time for change. Adelaide Law Review. Vol (37). 101, 103.

34. Low conviction rate. (2010, April 21). The Dawn.

35. Ma, Y. (2002). Prosecutorial Discretion and Plea Bargaining in the United States, France, Germany and Italy: Comparative Perspective, International Criminal Justice Review. Vol.12(1), p.22-52. ISSN: 1057-5677, 1556-3855.

36. Mack, R.L. (2006). It's Broke So Let's Fix It: Using a QuasiInquisitorial Approach to Limit the Impact of Bias in the American Criminal Justice System. Indiana International \& Comparative Law Review. Vol.7(1) 63-94,10.18060/17685.

37. Mehmood Ali and 3 others $v$. The State (2015 M L D 1560 [Lahore]),

38. Michael R. Pahl. (1992).Wanted: Criminal Justice-Colombia's Adoption of a Prosecutorial System of Criminal Procedure, Fordham International Law Journal, Vol.16(3). 608-634

39. Muhammad Ali v. Additional I.G., Faisalabad and others (P L D 2014 Supreme Court 753)

40. Muhammad Farooq Qureshi v. Judicial Magistrate S. 30 (2010 P Cr L J 261 Lahore) 
41. Nachkebia, G. (2016). Mixed Type Procedure Model or Adversarial Law? European Scientific Journal, SPECIAL/ edition. ISSN: 1857 7881 (Print) e - ISSN 1857- 7431.

42. Naveed Asghar v. State (2021 PLD 600 Supreme-Court)

43. Noor Hassan alias Noora v. State (2019 MLD 1671 Islamabad)

44. Pakes, F. (2007). The Changing nature of adversarial, inquisitorial, and Islamic trials, in applying psychology to criminal justice, ed. David Carson et al. London: Jhon Wiley \& Sons, Ltd.

45. Peake. J., (2014). Creating a hybrid system of procedure in international criminal law: a blending of adversarial \& Inquisitorial processes. International Law Students Association- ILSA Quart 22-28.

46. Peter G. Strasser. (2014). The Evolving Pakistani Criminal Justice System: A Study of the Raymond Davis Matter. Tulane Journal of International and Comparative Law, Vol. (23), 108-143.

47. PILDAT, (2016). Media Brief Prosecution Services and Media in Pakistan. Pakistan Institute of Legislative Development and Transparency, p-6, ISBN: 978-969-558-602-0; See also: Shah, S. (2016, March 11). Poor prosecution plays havoc with judicial system. The News International.

48. Pulecio-Boek, D. (2014). The genealogy of prosecutorial discretion in Latin America: A comparative and historical analysis of the adversarial reforms in the region. Richmond Journal of Global Law and Business, Vol.13(1), 67-144.

49. Punjab Criminal Prosecution Service (Constitution, Functions and Powers) Act 2006, Sindh C. P.S Ordinance 2006; Balochistan P. S Act VI of 2003; and NWFP P.S Act 2005.

50. Quadri, Kafayat Motilewa and Kadouf, Hunud Abia and Ishan Jan, Mohammad Naqib and Abdul Wahab, MohdIqbal and Ahamat, Haniff. (2019). Adquisitorial: the mixing of two legal systems. Journal of Education and Social Sciences. Vol. 13(1), ISSN 2289-9855. 129-137.

51. Rajput. M.A, \& Rajput. M.R, (2020). Impact of defective investigation and Prosecution on trial: Social Sciences, Vol. 9(1),265-268. doi=10.11648/j.ss.20200906.17

52. Rani, A, B, K.(2007). Between the adversarial and inquisitorial trial (2006), Malayan Law Journal. Vol.(2). [2007] 2MLJA 11. ISSN 00251283

53. Risinger, D.M. and Risinger. L.C. (2012). Innocence is different: taking innocence into account in reforming criminal procedure. New York Law School Law Review. Vol. 56(3).869-909; See also K.A. Findley. (2012). Adversarial inquisitions: rethinking the search for the truth. New York Law School Law Review. Vol.56(3).911-941 
54. Rule of law index.(2021, October).World Justice Project, USA, Andersen, E.,\& Ponce, A.(Eds.).The World Justice Project Rule of Law Index®2021.Retrieved from https://worldjusticeproject.org/ourwork/research-and-data/wjp-rule-law-index-2021

55. Sayed, S. H., Razak, M. A., \& H. L., Dr. (2019). Shariah Criminal Mode of Adjudication: Distinctive Features Vis- $\mathrm{A}-\mathrm{V}$ is Modern Systems. Journal of Education and Social Sciences, 13(1), 129-137. ISSN 2289-9855

56. Slobogin, C., (2014). Lessons from inquisitorialism. Southern California Law Review. (87)-699-732 Spamann, H. (2009). Contemporary Legal Transplants: Legal Families and the Diffusion of Corporate Law. Brigham Young University Law Review. Vol.2009(6). 1813-1867.

57. State v. Abdul Khaliq (PLD 2011 SC 554)

58. Thaman, Stephen C.(2010). A Typology of Consensual Criminal Procedures: An Historical and Comparative Perspective on the Theory and Practice of Avoiding the Full Trial. Chapter 11, World Plea Bargaining: Consensual Procedures and the Avoidance of the Full Criminal Trial, Carolina Academic Press. pp.297-396

59. The rule of law in Pakistan (2017): Key Findings from the 2017 Extended General Population Poll \& Justice Sector Survey. World Justice Project. https://worldjusticeproject.org/our-work/wjp-rulelaw-index/special-reports/rule-law-Pakistan

60. Three under-trial prisoners shot dead in courtroom. (2021, September 5). The Dawn.

61. U.S Department of Justice National Security Division. (n.d.). International Legal Systems - An Introduction. $\quad$ Office of Justice for Victims of Overseas Terrorism (DOJ/OVT). http://www.justice.gov/nsd/ovt

62. Under-trial prisoners 'victims of slow judicial system'. (2020, February 10). The Express Tribune.

63. Unfair Justice. (2020, September 17). The Dawn.

64. Urbano Martínez, José Joaquín. La nueva estructura probatoria del proceso penal. Bogotá: Ediciones Jurídicas Andrés Morales, 2008.

65. Velásquez, F (2019). El proceso penal de tendencia acusatoria: entre la inoperancia y el reformismo. Revista de Ciencias Sociales No. 74. Pp. $39-81$.

66. W. Liu; Y. Situ.(1999). Criminal Courts in China Transition: Inquisitorial Procedure to Adversarial Procedure?. Journal Crime \& Justice International. Vol.3(25), pp. 13-21 
European Scientific Journal, ESJ ISSN: 1857-7881 (Print) e - ISSN 1857-7431 February 2022 Bridging Language, Medicine, and Law

67. Walpin, G. (2003). American's Adversarial And Jury Systems: More Likely To Justice, Harvard Journal of Law and Public Policy, Vol. 26(1), p. 175

68. Watan Party and Another v. Federation of Pakistan and Others (PLD 2011 Supreme Court 997)

69. 4000 Judges Can Not Clear 1.9 M Cases. (2018, January 16). The Dawn. 